\title{
Comparative Nutritional and Storage Study of two Mandarin Varieties by Application of Various Salts Incorporated in Wax
}

\author{
Ehsan-U1-Haque ${ }^{1}$, Akbar Hayat ${ }^{1 *}$, Muhammad Asim ${ }^{1}$, Sajjad Hussain ${ }^{2}$, Muhammad Shakeel Hanif ${ }^{3}$, \\ Muhammad Zubair ${ }^{1}$, Muhammad Abdullah Jamil ${ }^{1}$ and Faheem Khadija ${ }^{1}$
}

${ }^{1}$ Citrus Research Institute, Sargodha, Punjab, Pakistan; ${ }^{2}$ Department of Horticulture, Bahauddin Zakariya University Multan, Pakistan; ${ }^{3}$ Fodder Research Institute, Sargodha, Punjab, Pakistan.

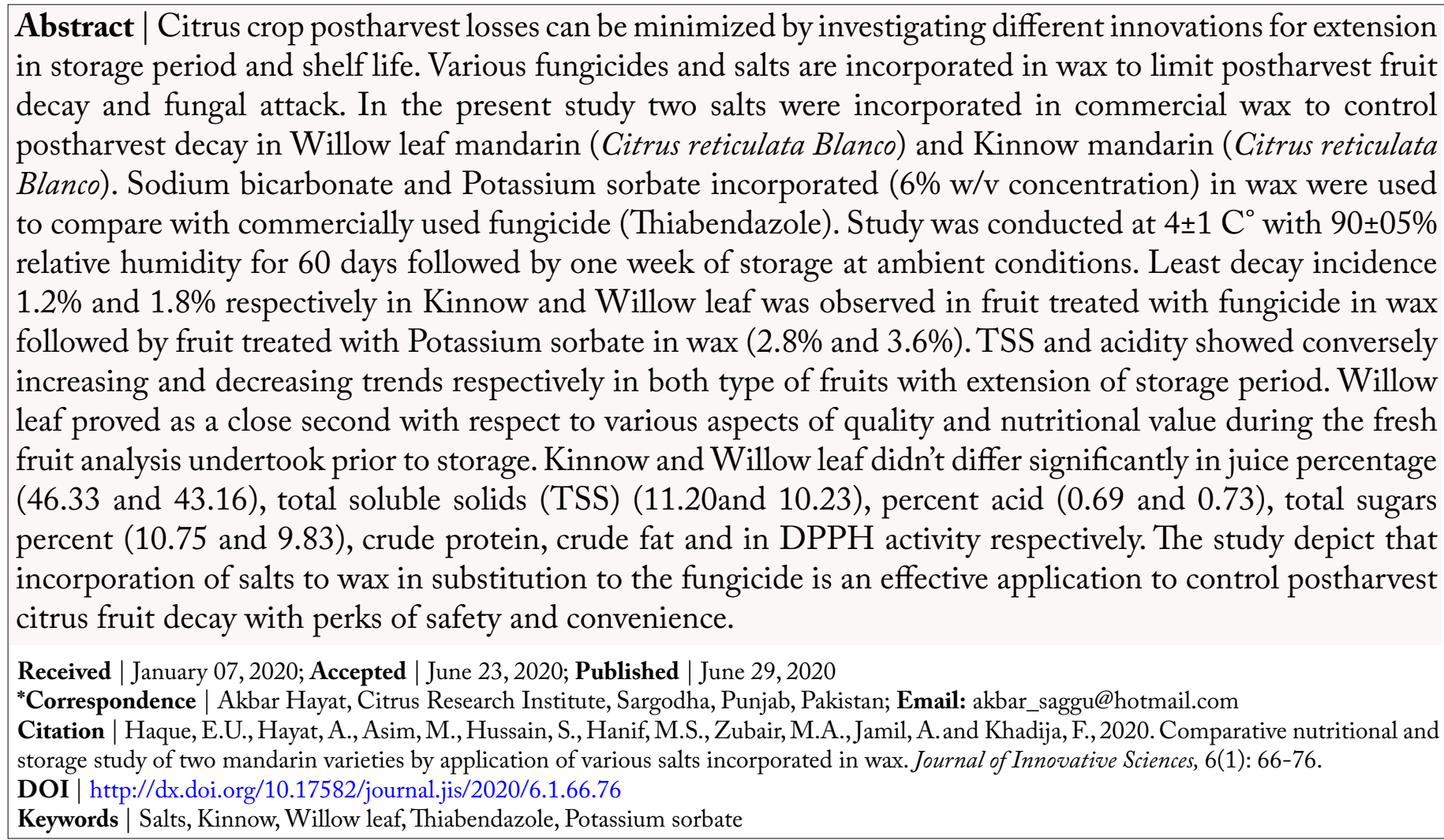

\section{Introduction}

W illowleaf is known undervarious regional names but most commonly called as Mediterranean mandarin is a commercial variety of Italy and Spain although cultivated in various other regions like Egypt, Brazil, Algeria and Argentina. Willow leaf is the pollen parent of three important hybrids Encore, Wilking and Kinnow along with King Mandarin as a seed parent (Reuther et al., 1967). Mediterranean mandarin Willow leaf has distinctive characteristics of mild and pleasantly aromatic flavor of juice while Kinnow, a King-Willow leaf mandarin hybrid is the major citrus fruit grown in Punjab Pakistan (Citrus Pages, 2011).

AlthoughbothMandarinvarieties KinnowandWillow leaf have good bearing potential but there is a problem of marked alternate bearing tendency which need to be carefully managed. In addition Willow leaf has highly delicate rind leading towards excessive decay losses during on-tree storage or either during post-harvest June 2020 | Volume 6 | Issue 1 | Page 66 
cold storage. Oil from rind and aromatic leaves of the Willow leaf are widely used in perfumes, flavoring, confectioneries and beverages (Hodgson, 1967).

Pakistan produces mandarins dominated by Kinnow in large quantities exporting to different countries of the world fetching more than $\$ 200$ Million revenue annually (TDAP, 2018) Citrus industry of Pakistan faces huge pre-harvest and post-harvest losses due to improper pre-harvest practices and postharvest management. Pre-harvest losses, low quality and poor yields at Pakistan citrus industry are mainly associated with low fruit set, malnutrition, water stress, insectpest complexes etc. situation is further aggravated by huge post-harvest losses (Nawaz et al., 2008).

One third citrus crop is wasted due to heavy postharvest losses ranging from 35 to $40 \%$ occurring at Pakistan citrus industry (PHDEB, 2014) are mainly associated to loss of quality linked with physiological disorders, pathological disorders leading to weight loss and microbial attack to the produce (Iqbal, 1996).

Qualitative losses are more difficult to measure than quantitative losses of fresh fruit. Post-harvest fruit losses in mandarin crop occur mainly due to improper methods of harvesting, handling, packing and transportation (Kader, 2005).

Literature (Palou et al., 2002; Gamagae et al., 2004; Gregori et al., 2008; Venditti et al., 2005; Mehyar et al., 2011) indicates that application of various salts mixed with wax is effective in reducing the postharvest fruit decay and weight loss.

Mixing of various salts in varying ratios with different waxes at the time of packing have been reported to clearly improve the post-harvest storage stability of citrus fruit thus reducing the decay and weight loss (E1-Mougy et al., 2008; Larrigaudiere et al., 2002; Palou et al., 2008; Valencia-Chamorro et al., 2009; Montero et al., 2010).

The present fresh fruit and storage study was conducted to compare nutritional value and bring improvement in shelf life and keeping quality of two mandarins i.e. Kinnow and Willow Leaf. Two salts in commercial wax were incorporated to enhance storage stability thus controlling postharvest decay and weight loss. Overall objective of the experiment was to improve the quality and storage stability of mandarin fruit.

\section{Material and Methods}

\subsection{Plant material, treatments and storage conditions}

This study was conducted at post-harvest division of Citrus Research Institute, Sargodha Pakistan during the citrus crop season year 2016-17.Mandarin varieties Kinnow and Willow leaf grafted on rough lemon root stock (Citrus jambhiri Lush).having planting age of seven years were selected for this study. Plants were spaced about $20 \times 20$ foot and managed under same inputs, cultural practices and agro-climatic conditions during the course of study. The study was carried out in a CRD design with three replications comprising of 20 fruits each separately for fresh fruit analysis and storage study Uniform mature fruits were selected for further physical, biochemical analysis and storage study. Mature fruit were harvested from the orchard during the month of January, washed, dried and divided into two lots. One lot was subjected to fresh fruit analysis while the second lot was waxed with prepared solutions in commercial wax according to the plan of storage study.

\subsection{Storage studies}

Fruit from both selected varieties Kinnow and Willow leaf were washed, waxed and dried according to the below mentioned treatment plan and stored for 60 days at constant climate chamber at $4 \pm 1{ }^{\circ} \mathrm{C}$ and 90 $\pm 05 \% \mathrm{RH}$ followed by one week of storage at ambient conditions. Fruit was analyzed for physiological loss in weight, decay percentage, TSS, acidity, loss in juice percentage at intervals of 0,30,60 days and last week of storage at ambient conditions. TSS and acidity was estimated as mentioned below (in fresh fruit analysis section) while juice and weight loss was calculated in percentage at given intervals on the basis of initial weight of juice and fresh fruit weight recorded at the time of storage. Fruit decay percentage was determined and calculated on the basis of percentage of decayed fruits on the given intervals as described by Rokaya et al., 2016 and Miri et al., 2018.

Different salts like sodium bicarbonate and potassium sorbate were incorporated in wax at $6 \%(\mathrm{w} / \mathrm{v})$ concentration to compare with commercially used fungicide Thiabendazole $(0.2 \%)$ in wax along with a control treatment having only (Fomesa- shellac based) wax.

Treatment plan observed for both mandarins separately was as following; 
T1= Fungicide Thiabendazole (0.2\%) added in wax; $\mathrm{T} 2=$ Sodium Bicarbonate $(6 \%)$ added in wax; $\mathrm{T} 3=$ Potassium Sorbate (6\%) added in wax; $\mathrm{T} 4=$ Wax only.

\subsection{Physico-chemical characteristics}

A representative sample of 20 mature fruits from each variety was selected, washed and dried to carry out the lab analysis. Fruit diameter (size) was measured by the use of digital caliper while fruit weight was measured by the use of digital electronic balance and average results were recorded in millimeter and gram respectively. Fruit firmness was measured by the usage of digital penetrometer in kilogram. Fruit juice was squeezed through electronic squeezer to calculate the average juice percentage per fruit. Peel thickness was measured in millimeters through digital caliper after removing the whiter albedo layer from the peel. All data measured was used to calculate the means of the measurements from the sample under study.

Acidity and Ascorbic acid (vitamin C) were determined and calculated as outlined by (AOAC, 2005). Total soluble solids (Brix) of juice were determined by the use of digital ATC Refractometer (automatic temperature compensation, corrected at $20{ }^{\circ} \mathrm{C}$ ) (make HANNA Japan) while $\mathrm{pH}$ was also recorded by the use of calibrated $\mathrm{pH}$ meter (make OHAUS corp. USA). Titratable acid (TA) percentage (citric acid $\mathrm{g}$ per $100 \mathrm{ml}$ ) was measured by titrating $10 \mathrm{ml}$ of juice against $0.1 \mathrm{~N} \mathrm{NaOH}$ solutions to the persistent pink color end point achieved at $\mathrm{pH}$ 8.1. All measurements were made in triplicate to record the averages as previously adopted by various researchers like Nawaz et al., 2019 and Miri et al., 2018. Ascorbic acid (Vitamin C mg/100 ml) was determined by diluting one $\mathrm{ml}$ of juice in oxalic acid solution (0.4\%), then volume was made to $10 \mathrm{ml}$ by distilled water and titrated against standard dye solution to persistent pink color end point.

\subsection{Total, reducing and non-reducing sugars (\%)}

Total, reducing and non-reducing sugar percentage was determined as described in AOAC, 1995.

The juice sample $(10 \mathrm{ml})$ was filtered and added in $250 \mathrm{ml}$ volumetric flask, $10 \mathrm{ml}$ potassium oxalate (7\%) and $25 \mathrm{ml}$ lead acetate (2\%) was also added to the solution. Volume was made with distilled water. Prepared sample was titrated against Fehling solution till red precipitates appeared. The percentage of reducing sugars was calculated as following:
Reducing sugars $(\mathrm{g} / 100 \mathrm{ml}, \%)=6.25(\mathrm{X}) / \mathrm{Y}$

Where; $\mathrm{X}=\mathrm{ml}$ of standard sugar solution used and $\mathrm{Y}=$ $\mathrm{ml}$ of sample aliquot used against Fehling solution.

For determination of total sugars $25 \mathrm{ml}$ sample aliquot was taken in $100 \mathrm{ml}$ volumetric flask in which $20 \mathrm{ml}$ distilled water and $5 \mathrm{ml}$ concentrated $\mathrm{HCl}$ was added and kept overnight to convert non-reducing sugars into reducing sugars. Concentrated $\mathrm{NaOH}$ (50\%) was then added to neutralize the solution and distilled water was added to make the volume. The solution was added to a graduated burette and titration against $10 \mathrm{ml}$ Fehling's solution was conducted by adding phenolphthalein indicator to the brick red end point. Total sugars percentage was calculated as;

$$
\text { Total sugars }(\mathrm{g} / 100 \mathrm{ml}, \%)=25(\mathrm{X}) / \mathrm{Z}
$$

Where; $X=m l$ of standard sugar solution used and $Z=$ $\mathrm{ml}$ of sample aliquot used against Fehling solution.

Non-reducing sugars $(\mathrm{g} / 100 \mathrm{ml}, \%)=$ Total sugars $\%$ Reducing sugars \% x 0.95

\subsection{Proximate analysis}

Proximate analysis of juice for determination of crude protein, crude fat, crude fiber and total ash was carried out as described in AOAC, 2012. Crude protein was calculated through nitrogen percentage (Nitrogen \% X 6.25) determined by Kjeldahl's method. Nitrogen percentage from prepared sample was determined through titration against $0.1 \mathrm{~N} \mathrm{H}_{2} \mathrm{SO}_{4}$ till golden yellow end point. Crude fat was determined by Soxhlet's apparatus in which dried sample was extracted in petroleum ether which was dried and weighed in a petri dish. Total Ash from sample was determined by weighing the dry mineral residues heated in muffle furnace maintained at $550 \mathrm{C}^{\circ}$. Crude fiber was obtained by digesting sample with $\mathrm{H}_{2} \mathrm{SO}_{4}$ and $\mathrm{NaOH}$ and heating the residues in a muffle furnace at elevated temperature of $550^{\circ} \mathrm{C}$.

\subsection{Ascorbic acid, $\beta$-carotene and Antioxidant Activity (DPPH)}

Vitamin C (Ascorbic acid) was determined as described by AOAC, 1995 in which diluted sample was titrated against standard dye solution. For determination of beta carotene, fruit sample was soaked in methanol under dark conditions to completely extract the carotene contents. Carotene 
layer separated with hexane and Sodium Sulphonate was passed through separating funnel and absorbance was measured at $436 \mathrm{~nm}$ as described by Ranganna (1999).

Fruit samples were analyzed for antioxidant activity (DPPH) percentage by using published procedure as by Thaipong et al. (2006). Pure ethanol based plant extract with DPPH working solution was kept in laminar chamber and absorbance was checked at 515 $\mathrm{nm}$ on spectrometer. Prepared stock solution was also checked at wavelength $517 \mathrm{~nm}$ and blank sample without plant extract prepared with ethanol and working solutions was checked at $515 \mathrm{~nm}$ wavelength and calculated as following;

Antioxidant activity \% $(\mathrm{DPHH})=(\mathrm{A}$ blank $-\mathrm{A}$ sample) / A blank

\subsection{Statistical analysis}

Fresh fruit analysis and storage study was carried out in a completely randomized design (CRD) with three replicates The Analysis of Variance was conducted using statistix 8.1 and means were compared by LSD test at $\mathrm{P} \leq 0.05$.

\section{Results and Discussion}

\subsection{Fresh fruit comparison}

\subsubsection{Physico-chemical characteristics}

The research study was carried out to explore the quality and nutritional comparison of the two promising mandarin varieties i.e. Kinnow and Willow leaf. A Commercial mandarin variety, Willow leaf of leading producers like Italy, Spain; a pollen parent of Kinnow was compared with Kinnow (predominant of local citrus industry) for nutritional value, quality and storage stability. Results of the fresh fruit analysis and storage study showed Willow leaf as a new promising substitute of Kinnow.

Although with respect of average fruit weight Kinnow has attained a bigger size (162.96 g) as compared to fruit of Willow leaf $(122.58 \mathrm{~g})$ but there was no significant difference found in the juice percentage attained from the two contestant varieties. Average fruit diameters of the two mandarins also did not differ significantly (Table 1). In case of fruit firmness Willow leaf was not found at par with Kinnow as Willow leaf has found a thin peel $(2.12 \mathrm{~mm})$ as compared to that of Kinnow $(2.82 \mathrm{~mm})$.

Fruit weight and size are important physicochemical characteristics of fruit which mainly define the juice recovery from the fruit which is ultimately desired for fresh fruit consumer and processor. According to Fonfría et al., 1996 various factors define fruit size in which fruit position on stem, competitiveness among growth organs and genotype are important. Kinnow mandarin had significantly better weight of fruit but both mandarins did not differ in juice recovery in which peel weight from Kinnow fruit might be greater than that of Willow leaf which possess lesser peel thickness (Table 1). Results of various physicochemical parameters for Kinnow and Willow leaf were found in accordance with the results found by Neves et al., 2018; Ahmad et al., 2013 and Khan et al., 2008. Various pre-harvest factors like climatic and soil conditions and availability of various inputs on different crop maturity stages affect the fruit quality parameters. Koshita, 2015 stated that low temperatures intensify coloration of skin and availability of irrigational water helps to enhance juice recovery at maturity phase in citrus crop.

Table 1: Physico-chemical characteristics of fresh fruit of Kinnow and Willow leaf Mandarins.

\begin{tabular}{llllll}
\hline Variety & Fruit weight $(\mathbf{g})$ & Fruit diameter $\mathbf{( m m )}$ & Fruit firmness $\mathbf{( K g )}$ & Peel thickness $(\mathbf{m m})$ & Juice $(\%)$ \\
\hline Kinnow & $162.96 \pm 10.44 \mathrm{a}$ & $71.03 \pm 3.92 \mathrm{a}$ & $2.42 \pm 0.1 \mathrm{a}$ & $2.82 \pm 0.16 \mathrm{a}$ & $46.33 \pm 1.45 \mathrm{a}$ \\
Willowleaf & $122.58 \pm 7.33 \mathrm{~b}$ & $64.33 \pm 3.37 \mathrm{a}$ & $1.87 \pm 0.08 \mathrm{~b}$ & $2.12 \pm 0.012 \mathrm{~b}$ & $43.16 \pm 0.72 \mathrm{a}$ \\
\hline
\end{tabular}

Data are means \pm SE of triplicate determinations. LSD test $\leq 0.05 \%$ used for analysis

Table 2: Physico-chemical characteristics of fresh fruit of Kinnow and Willow leaf Mandarins.

\begin{tabular}{lllll}
\hline Variety & TSS(Brix) & Acidity (TA) \% & TSS/Acid ratio & pH \\
\hline Kinnow & $11.20 \pm 0.65 \mathrm{a}$ & $0.69 \pm 0.05 \mathrm{a}$ & $16.01 \pm 1.1 \mathrm{a}$ & $3.74 \pm 0.22 \mathrm{a}$ \\
Willowleaf & $10.23 \pm 0.54 \mathrm{a}$ & $0.73 \pm 0.04 \mathrm{a}$ & $13.73 \pm 0.09 \mathrm{a}$ & $3.68 \pm 0.21 \mathrm{a}$ \\
\hline
\end{tabular}

Data are means \pm SE of triplicate determinations. LSD test $\leq 0.05 \%$ used for analysis. 
Fruit from both contestant mandarin varieties did not differ significantly in parameters like total soluble solids (TSS), Titratable acidity (TA), TSS/TA ratio and $\mathrm{pH}$. In Kinnow average TSS was observed 11.2\% while in Willow leaf as $10.2 \%$ (Table 2) while in case of TA both varieties showed $0.69 \%$ and $0.73 \%$ for Kinnow and Willow leaf respectively.

Table 3: Physico-chemical characteristics (Sugars) of fresh fruit of Kinnow and Willow leaf Mandarins.

\begin{tabular}{llll}
\hline Variety & $\begin{array}{l}\text { Total sugars } \\
\mathbf{( \% )}\end{array}$ & $\begin{array}{l}\text { Reducing } \\
\text { sugars (\%) }\end{array}$ & $\begin{array}{l}\text { Non-Reducing } \\
\text { sugars (\%) }\end{array}$ \\
\hline Kinnow & $10.75 \pm 0.33 \mathrm{a}$ & $4.60 \pm 0.32 \mathrm{a}$ & $6.16 \pm 0.44 \mathrm{a}$ \\
Willowleaf & $9.83 \pm 0.35 \mathrm{a}$ & $4.68 \pm 0.33 \mathrm{a}$ & $5.09 \pm 0.05 \mathrm{~b}$ \\
\hline
\end{tabular}

Data are means \pm SE of triplicate determinations. LSD test $\leq$ $0.05 \%$ used for analysis.

Mandarins like Kinnow and Willow leaf are cherished in global citrus industry due to their reasonable size, nutritional value, physicochemical properties, sensory attributes and antioxidant characteristics (Ahmad et al., 2013). Kinnow showed a high degree of variation in various physicochemical characteristics like fruit size, shape, $\mathrm{pH}$, TSS and various other parameters but it is adopted dominant citrus in Pakistan due to its capability to tolerate heat waves sometimes touching to $45{ }^{\circ} \mathrm{C}$; this heat resistance is inherited from its parent cultivar King (Altaf et al., 2008). Results for the various physicochemical parameters like fruit weight, size, peel thickness, TSS and acidity for Kinnow were found in accordance with that stated by Khan et al., 2008.

\subsection{Physico-chemical characteristics (Sugars)}

Both candidate mandarin varieties had no significant difference in sugar percentage except that Willow leaf had lower percentage of non-reducing sugars (5.09\%) as compared to Kinnow (6.16\%). Reducing sugars and total sugars percentage of both mandarins had showed no significant difference (Table 3 ). The sugars level increase with progression of fruit towards maturity (Hardy and Sanderson, 2010). Citrus fruit carbohydrates mainly consist of sugars; glucose, fructose (combined called reducing sugars) and sucrose (non-reducing sugar) which define the sweetness of fruit juice Hulme, 1971. The ratio of reducing to nonreducing sugars may alter with maturity, in different varieties of citrus during storage Daito and Sato, 1985. Results for sugars in both varieties were found as previous finding stated by Liu et al., 2012; Nawaz et al., 2019 and Neves et al., 2018.

\subsection{Proximate analytical quality}

Results of the proximate analysis showed that Kinnow and Willow leaf did not differ significantly in crude protein and crude fat percentage but both differ significantly for crude fiber percentage $(2.23 \%$ and $1.85 \%$ respectively). There was also significant difference found among two mandarins for ash percentage; $0.41 \%$ for Kinnow and $0.38 \%$ for Willow leaf (Graph-1).

Source of dietary fiber is considered polysaccharides present in peel and pulp of citrus fruits (Spungen, 2005) in which generally insoluble portion is composed of pectin, cellulose and lignin which has ability to prevent digestive disorders (Hillemeier, 1995) with benefit of lowering cholesterol (Ting, 1980). Citrus fruits are not major source of proteins. Protein is determined by total Nitrogen content of the juice which is mostly contributed by free amino acids (Zamorani and Russo, 1974). Free amino acids present in citrus juices have only little impact on human nutrition as predominant portion is consisted on non-essential amino acids dominated by proline except lime juice (Ladanyia and Ladaniya, 2010; USDA, 2011). Fats (lipids) are mostly concentrated in the seed and rind of the citrus fruit while flesh of fruit is not a good source of fats. Outer part of the fruit surface is covered by cuticle lipids which are a natural protection to insect pest attack, chilling injury and moisture loss (Nordby and McDonald, 1991). Ash percentage indicates the dried mineral residues concentration in citrus juice. There are various mineral elements present in citrus fruits which are dominated by Potassium cations which contribute almost $40 \%$ of the total ash contents (Benk, 1965; USDA, 2011).

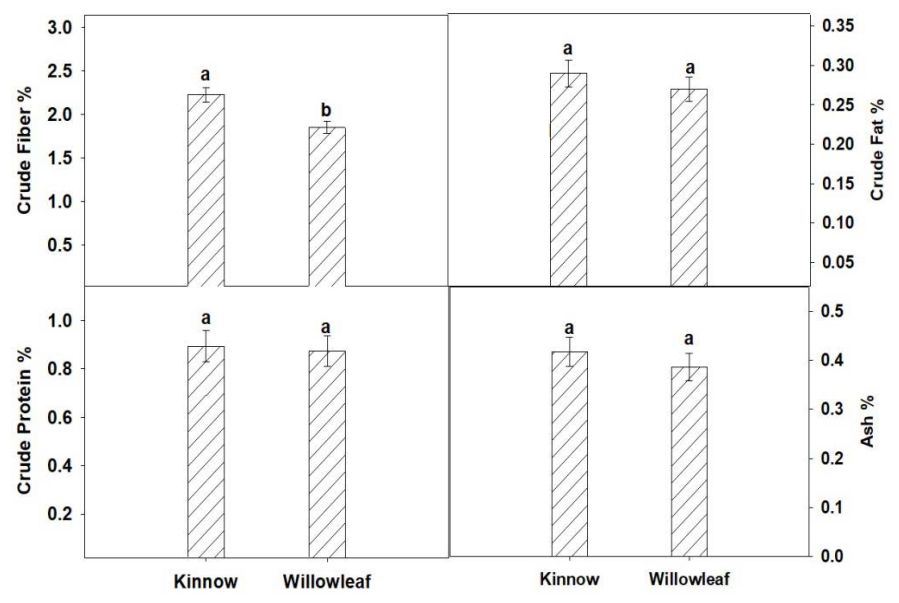

Graph 1: Proximate analysis of fresh fruit of Kinnow and Willow leaf Mandarins. 
3.4 Ascorbic acid, $\beta$-carotene and antioxidant activity (DPPH)

Results for ascorbic acid (vitamin $\mathrm{C}$ indicates that Kinnow fruit have better concentration of vitamin C $(39.21 \mathrm{mg} / 100 \mathrm{ml})$ as compared to Willow leaf $(31.52$ $\mathrm{mg} / 100 \mathrm{ml})$. In case of beta carotene contents both mandarin varieties did not differ significantly having 63.12 and $60.47 \mu \mathrm{g} / 100 \mathrm{~g}$ respectively for Kinnow and Willow leaf. Antioxidant activity measured as DPPH in Kinnow and Willow leaf mandarins was also remained at par showing values of 71.03 and $71.77 \%$ respectively (Graph-2).

Most important element provided by citrus fruit for human health and nutrition is vitamin $\mathrm{C}$ (ascorbic acid). Vitamin $\mathrm{C}$ is a water soluble vitamin which is found in considerable concentrations in citrus fruits. Vitamin $\mathrm{C}$ in citrus fruits and their products is found in variable concentrations depending upon stage of maturity, variety, handling, climate, storage and processing conditions (Liu et al., 2012). Citrus fruits providing average quantities of daily requirement are considered rich and popular source of vitamin $\mathrm{C}$ ranging from 23 to $83 \mathrm{mg} / 100 \mathrm{~g}$ of fresh edible portion (Lee and Kader, 2000). Recommended dietary allowance (RDA) by USDA for adults regarding vitamin $\mathrm{C}$ is $75-90 \mathrm{mg}$.

The only fat soluble vitamin present in citrus fruits is vitamin $\mathrm{A}$ found in the form of provitamin $\mathrm{A}$ commonly called carotenoids ( $\alpha$ carotene, $\beta$ carotene and $\beta$-cryptoxanthin). Carotenoids are found to act as antioxidants reducing various degenerative diseases and found in variable quantities in different citrus fruits as mandarins are considered valuable dietary source followed by pink grapefruits and oranges (USDA, 2011; Holden et al., 1999). Vitamin A precursors $\beta$-cryptoxanthin are found in various fruits and vegetables like papaya, red chilies, pumpkins, peaches, guava but citrus fruits are considered the best rich source (Arscott et al., 2010; Burri et al., 2011). In comparison with oranges Dhuique-Mayer et al., 2005 found that Mandarins and their hybrids like clementine are best source of vitamin $\mathrm{A}$.

$\mathrm{DPPH}$ is an easy determination of antioxidant activity in the citrus juices. DPPH is a free radical which is reduced by accepting an electron from the molecules of antioxidants which are able to donate Hydrogen atom, resulting in stable molecule in the result of reduction in DPPH and yielding colorless ethanol solutions (Kour et al., 2014; Rekha et al., 2012). Antioxidants are bioactive compounds promoting various biological functions to prevent from cancer, cardiovascular disorders, diabetes and many other malfunctions in the human body (Ke et al., 2015; Rajendran et al., 2014).

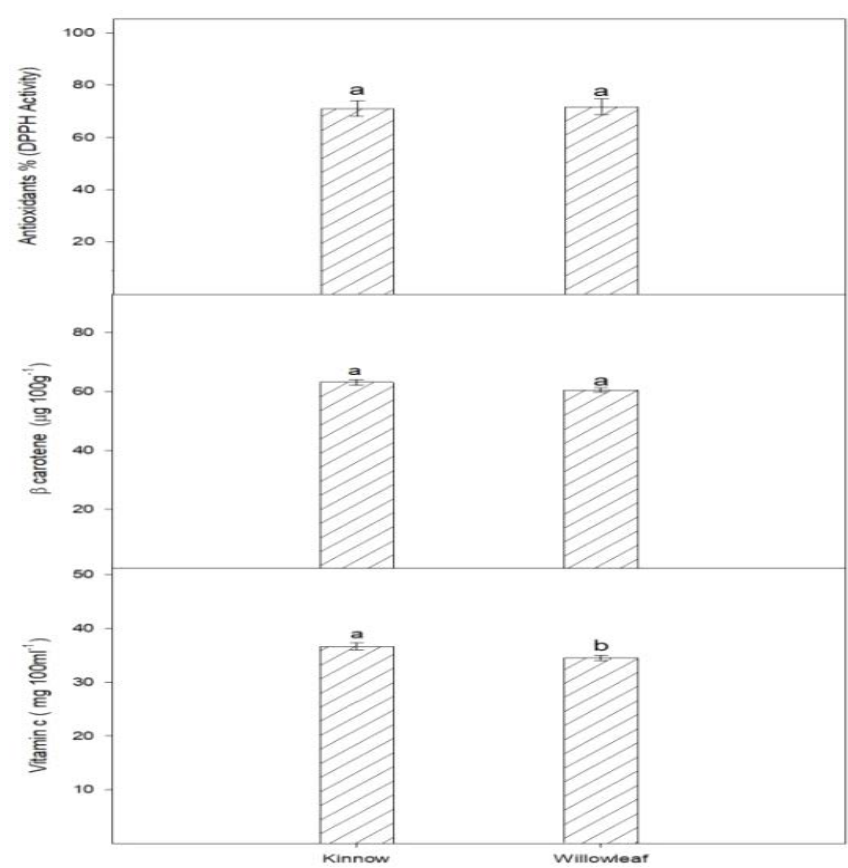

\section{Graph 2: Ascorbic acid, $\beta$-carotene and Antioxidant Activity of fresh fruit of Kinnow and Willow leaf Mandarins.}

\subsection{Postharvest fruit storage studies}

Storage studies were carried out against parameters like physiological loss in weight, decay percentage, juice percentage, TSS and acidity. The perusal from data and graphs shown below the decay percentage (Graph 4) and weight loss percentage (Graph 3) was increased in all treatments in both mandarin varieties significantly with prolongation of storage period. Maximum decay percentage was noticed in T4 in fruits treated only with wax while minimum decay percentage was noticed in T1 in which fruit was treated with Thiabendazole fungicide in both type of mandarins. Same trend was followed by both mandarins in weight loss percentage with respect to four treatments. Graph 5 shows the juice recovery percentage which was decreased with storage period in all four treatments in both varieties but more significantly decrease was observed in case of Willow leaf mandarin. Total soluble solids increased with progression of storage period and titratable acidity (Graph 6 \& Graph 7) decreased with advancement of the storage period in all treatments in both mandarin varieties. 


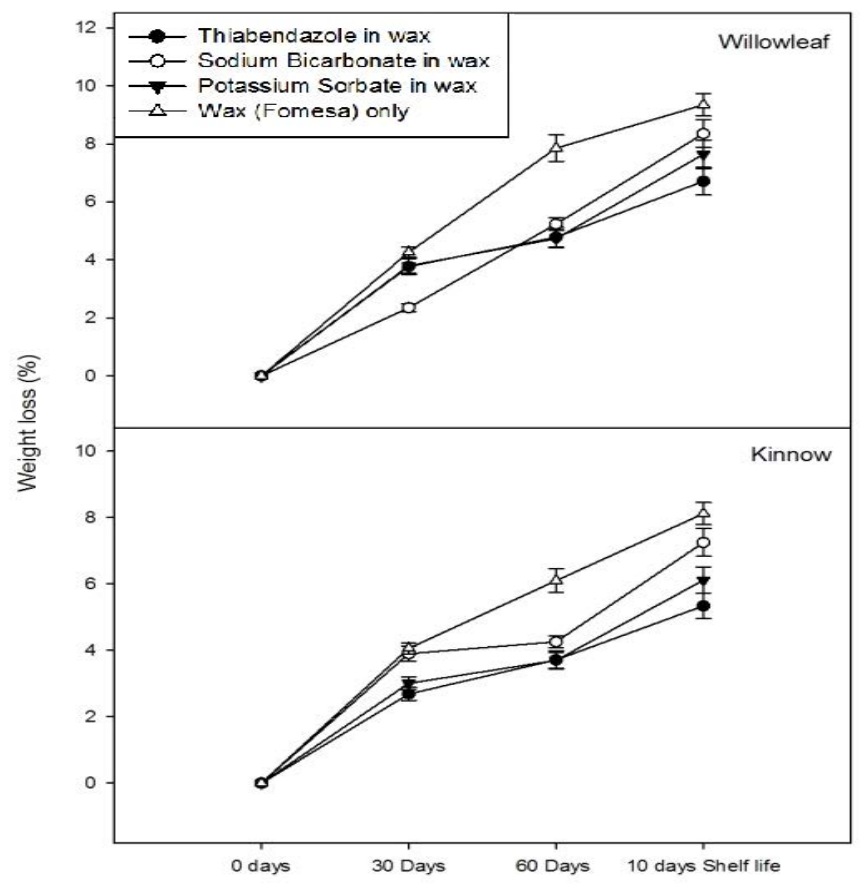

Graph 3: Effect of postharvest treatments on fruit weight loss in Kinnow and Willow leaf Mandarins.

Minimum weight loss was observed in case of Kinnow treated with thiabendazole kept for one week at ambient conditions after 60 days storage at controlled conditions. In the same treatment adopted for Willow leaf weight loss percentage was significantly higher than that for Kinnow.

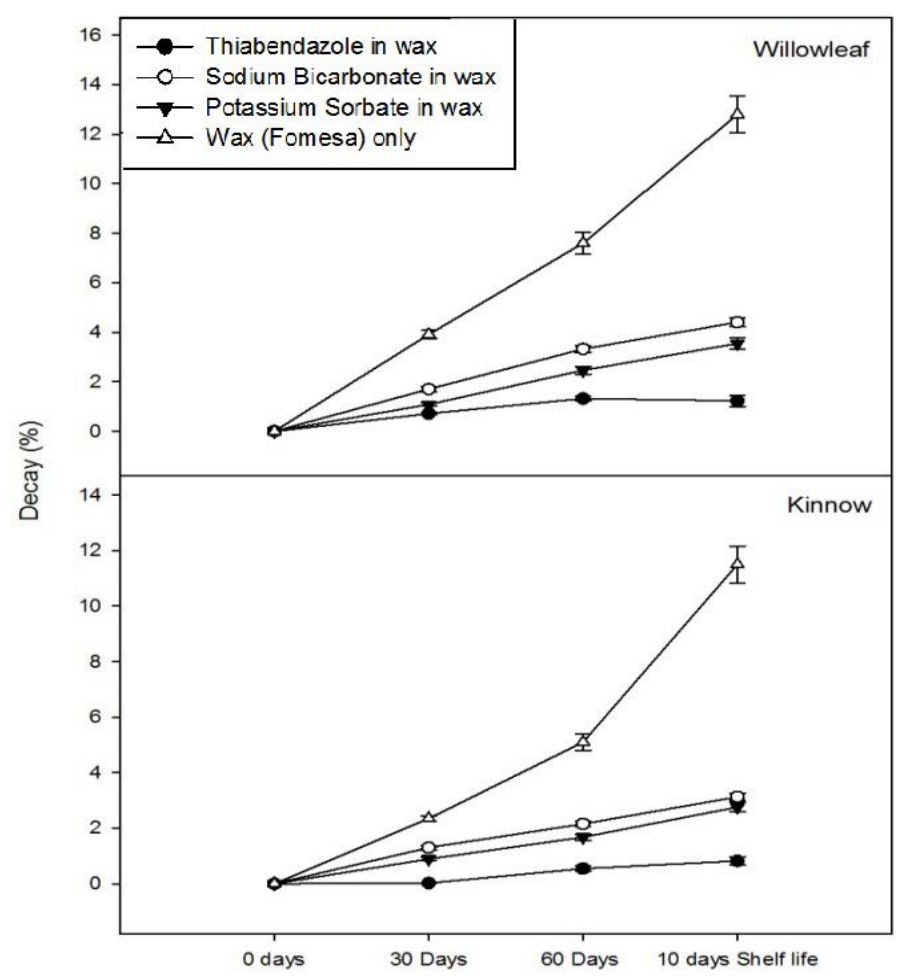

Graph 4: Effect of postharvest treatments on fruit decay in Kinnow and Willow leaf Mandarins.

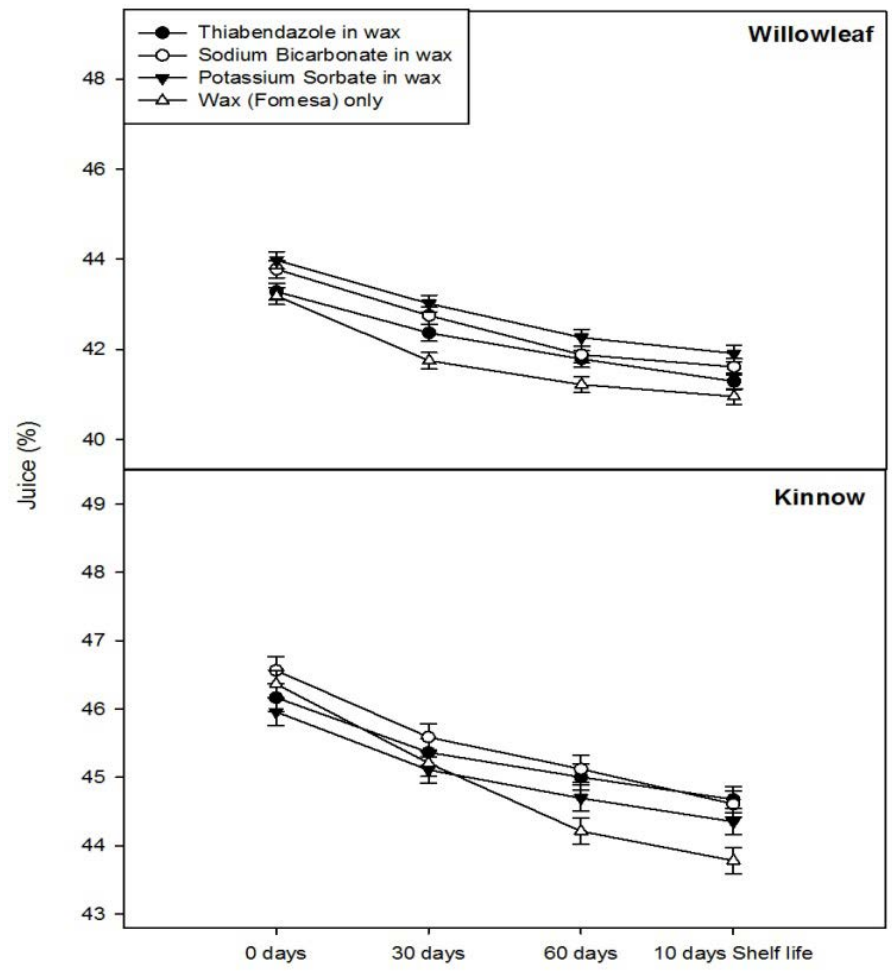

Graph 5: Effect of postharvest treatments on fruit juice recovery in Kinnow and Willow leaf Mandarins.

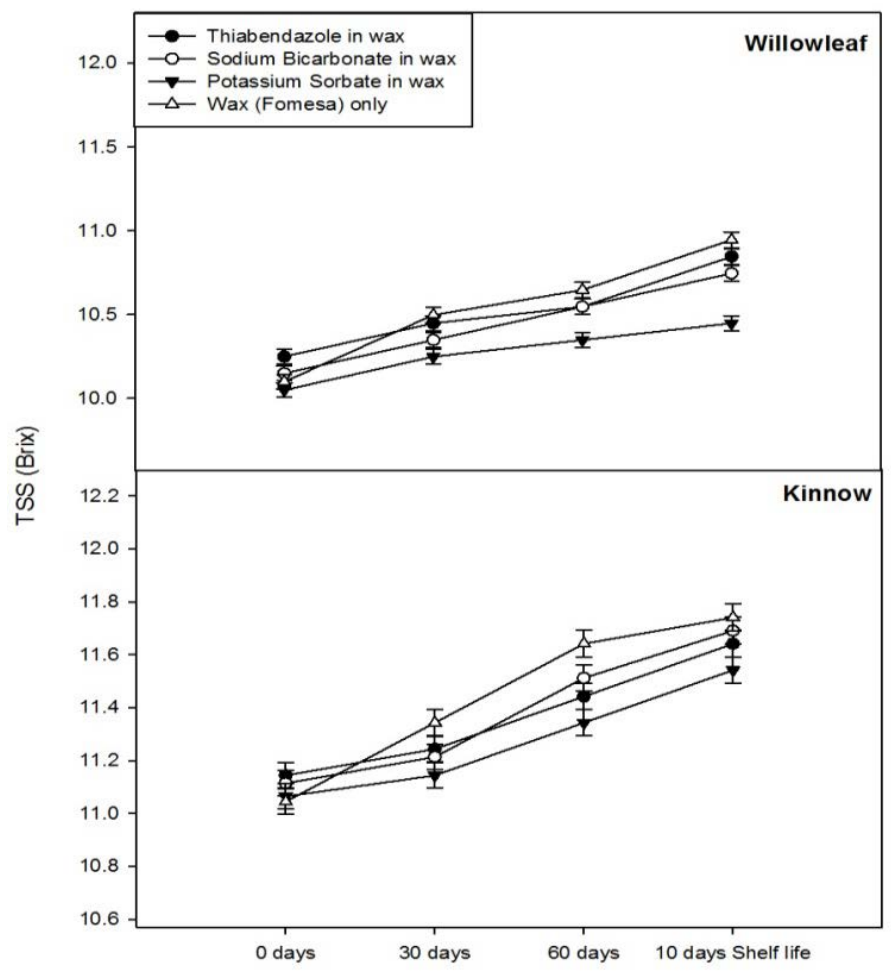

Graph 6: Effect of postharvest treatments on fruit juice TSS in Kinnow and Willow leaf Mandarins.

Physiological weight loss and reduction in juice recovery in all treatments was recorded minimum attributed to wax coating which retard the respiration and moisture transpiration from surface of fruit assisted by environmental temperature and relative 
humidity. Thus application of wax in combination with fungicide and salts was found quite helpful to retain glossiness avoiding wilting and skin shriveling as studied by Wills et al., 1999; Mahajan et al., 2004.

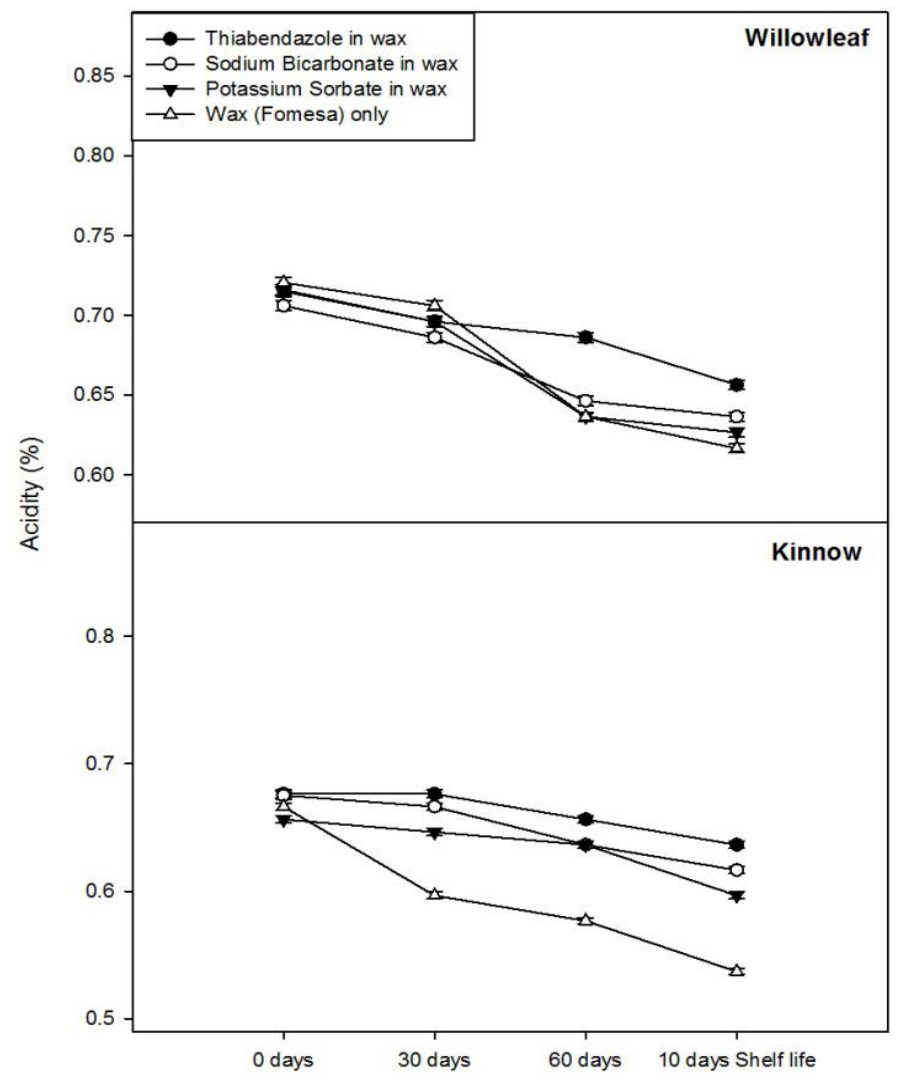

Graph 7: Effect of postharvest treatments on fruit juice acidity in Kinnow and Willow leaf Mandarins.

Minimum decay percentage in both fruit under test was seen in a fungicide treatment $\mathrm{T} 1$ with prolongation of storage period followed by T3 and T2 in which fruit was treated with Potassium Sorbate and Sodium Bicarbonate respectively. The results indicated the effective control of fruit decay achieved by the combination of two salts with wax confirming results previously obtained by El-Mougy et al., 2008 and Youssef et al., 2012.

TSS (Brix) and acidity mainly determine the fruit maturity indices and serve to determine the quality of fruit. TSS in both mandarins increased with prolongation of storage period while acidity showed a decreasing trend. Incremental trend in TSS can be attributed due to metabolic activities converting polysaccharides into sugars and reduction of moisture level due to transpiration and evaporation. The linear decline in acidity might be due to catabolism of organic acids (Mahajan et al., 2016). Overall results for TSS and acidity were found in accordance with findings of Rab et al., 2016, Sonkar et al., 2009, Youssef et al., 2012.

\section{Conclusions and Recommendations}

Postharvest losses can be minimized through best postharvest management practices and by extending storage stability of citrus fruit. Waxing with incorporated salts like Potassium Sorbate and Sodium Bicarbonate can effectively control postharvest diseases and decay in Mandarin fruits resulting in improved quality of fruit. Kinnow and Willow leaf mandarins exhibit well balanced nutritional status and can be stored up to 60 days at optimal storage conditions after proper postharvest treatment.

\section{Acknowledgement}

The authors would like to thank the Punjab Agriculture research Board (PARB), Lahore for financial support and Biochemistry section/Post-harvest Research Institute AARI Faisalabad for facilitating Laboratory and analytical work.

\section{Author Contribution}

The authors Ehsan-U1-Haque and Akbar Hayat designed, directed and executed the project. Muhammad Zubair, Muhammad Abdullah Jamil and Faheem Khadija performed the experiments. Muhammad Asim, Muhammad Shakeel Hanif developed the framework and wrote the article. Sajjad Hussain reviewed the whole manuscript critically.

\section{Conflict of interest}

The authors have declared no conflict of interest.

\section{References}

AOAC, 1995. Official methods of analysis. Association of official analytical chemists, $15^{\text {th }}$ Edi. Washington DC, USA

AOAC, 2005. Official methods of analysis. Association of official analytical chemists, Washington DC, USA.

AOAC, 2012. Official methods of analysis. $19^{\text {th }}$ ed., Vol. I. Association of official analytical chemists, Washington, D.C. USA.

Ahmad, M.S., Thakur, K.S. and Siddiqui, M.W., 2013. Postharvest treatments for preserving quality of 'Kinnow' fruit under different storage 
conditions. Adv. Hortic. Sci., 27(4): 1-7.

Altaf, N., Khan, A.R. and Hussain, J., 2008. Fruit variability in Kinnow mandarin (Citrus reticulata). Pak. J. Bot., 40(2): 599-604.

Arscott, S.A., Howe, J.A., Davis, C.R. and Tanumihardjo, S.A., 2010. Carotenoid profiles in provitamin A- containing fruits and vegetables affect the bioefficacy in Mongolian gerbils. Exp. Biol. Med., 235: 839-848. https:// doi.org/10.1258/ebm.2010.009216

Benk, E., 1965. Content of inorganic materials, especially sodium, in natural orange juice. Mitt. Geb. Lebensmittelunters Hyg., 56: 273-281.

Burri, B.J., Chang, J.S.T. and Neidlinger, T.R., 2011. $\beta$-Cryptoxanthin- and $\alpha$-carotene-rich foods have greater apparent bioavailability than $\beta$-carotene-rich foods in Western diets. Br. J. Nutr., 105: 212-219. https://doi.org/10.1017/ S0007114510003260

Citrus Pages, 2011. Available at: http://citruspages. free.fr/mandarinhybrids.html\#kinnow (accessed 30 Dec 2019).

Daito, H. and Sato, Y., 1985. Changes in the sugar and organic acid components of Satsuma fruits during maturation. J. Japanese Soc. Hortic. Sci., 54: 155-162. https://doi.org/10.2503/ jjshs. 54.155

Dhuique-Mayer, C., Caris-Veyrat, C., Ollitrault, P., Curk, F. and Amiot, M.J., 2005. Varietal and interspecific influence on micronutrient contents in citrus from the Mediterranean area. J. Agric. Food Chem., 53(6): 2140-2145. https://doi.org/10.1021/jf0402983

El-Mougy, N.S., El-Gamal, N.G. and AbdEl-Kareem, F., 2008. Use of organic acids and salts to control postharvest diseases of lemon fruits in Egypt. Arch. Phytopathol. Plant Prot., 41(7): 467-476. https://doi. org/10.1080/03235400600813532

Fonfría, M.A., Orega, V.A., Ferrer, M.J. and Romero, V.E., 1996. Citros: Development and final fruit size. P. Alegre. pp. 102.

Gamagae, S.U., Sivakumar, D. and Wijesundera, R.L.C., 2004. Evaluation of postharvest application of sodium bicarbonate incorporated wax formulation and Candida oleophila for the control of anthracnose of papaya. Crop Prot. 23: 575-579. https://doi.org/10.1016/j. cropro.2003.11.003

Gregori, R., Borsetti, F., Neri, F., Mari, M. and Bertolini, P., 2008. Effects of potassium sorbate on postharvest brown rot of stone fruit. J. Food Prot., 71: 1626-1631. https://doi. org/10.4315/0362-028X-71.8.1626

Hardy, S. and Sanderson, G., 2010. A procedural manual for citrus maturity testing. NSW Department of Industry and Investment, Australia.

Hillemeier, C., 1995. An overview of the effects of dietary fiber on gastrointestinal transit. Pediatrics. 96: 997-999.

Hodgson, R.W., 1967. Horticultural varieties of citrus. Hist. World Dist., Bot. Varieties. pp. 431-591.

Holden, J.M., Eldridge, A.L., Beecher, G.R., Buzzard, I.M., Bhagwat, S., Davis, C.S. and Schakel, S., 1999. Carotenoid content of US foods: an update of the database. J. Food Compos. Anal., 12(3): 169-196. https://doi. org/10.1006/jfca.1999.0827

Hulme, A.C., 1971. The biochemistry of fruits and their products. The biochemistry of fruits and their products. 2: 107-179.

Iqbal, M., 1996. Type and extent of postharvest losses in horticultural commodities in Pakistan. Proc. Natl. Conf. Postharvest Technol. Hortic. Commodities, Quetta, Pak. pp. 10-12.

Kader, A.A., 2005. Increasing food availability and reducing postharvest losses of fresh produce. Proc. $5^{\text {th }}$ Int. Postharvest Symp., Verona, 6-11 June 2004, pp. 2169-2175. https://doi. org/10.17660/ActaHortic.2005.682.296

Ke, Z., Xu, X., Nie, C. and Zhou, Z., 2015. Citrus flavonoids and human cancers. J. Food Nutr. Res., 3(5): 341-351. https://doi.org/10.12691/ jfnr-3-5-9

Khan, M.M., Mumtaz, S., Ahmad, S., Abbas, M. and Khan, I.A., 2008. Some studies on the morphology of Kinnow mandarin and Feutrell's early. Pak. J. Agric. Sci., 42: 424-431.

Koshita, Y., 2015. Effect of temperature on fruit color development. In: Kanayama, Y.K.A. (Eds.), Abiotic Stress Biology in Horticultural Plants. Springer, Tokyo. https://doi.org/10.1007/9784-431-55251-2_4

Kour, R., Rastogi, A., Sharma, R.K., Kumar, A. and Raghuwanshi, P., 2014. Chemical composition, anti-oxidative activity and in vitro dry matter degradability of Kinnow mandarin fruit waste. Vet. World. 7(10): 803-806. https://doi. org/10.14202/vetworld.2014.803-806

Larrigaudiere, C., Pons, J., Torres, R. and Usall, 
J., 2002. Storage performance of Clementines treated with hot water, sodium carbonate, and sodium bicarbonate dips. J. Hortic. Sci. Biotechnol., 77: 314-319. https://doi.org/10.1 080/14620316.2002.11511499

Ladanyia, M. and Ladaniya, M., 2010. Citrus fruit: Biology, technology and evaluation. Academic press.

Lee, S.K. and Kader, A.A., 2000. Preharvest and postharvest factors influencing vitamin C content of horticultural crops. Postharvest Biol. Technol.,20:207-220.https://doi.org/10.1016/ S0925-5214(00)00133-2

Liu, Y., Heying, E. and Tanumihardjo, S.A., 2012. History, global distribution, and nutritional importance of citrus fruits. Compr. Rev. Food Sci. Food Saf., 11(6): 530-545. https://doi. org/10.1111/j.1541-4337.2012.00201.x

Mahajan, B.V.C., Dhatt, A.S. and Dhillon, W.S., 2004. Effect of pre-storage treatments on the quality and storage life of Asian pear. Indian J. Hortic., 61(4): 342-344.

Mahajan, B.V.C., Singh, R. and Kumar, M., 2016. Quality assurance and shelf-life extension of Kinnow mandarin fruit under supermarket conditions. Int. J. Fruit Sci., 16(1): 94-102. https://doi.org/10.1080/15538362.2015.10619 59

Mehyar,G.F.,Al-Qadiri,H.M.,Abu-Blan,H.A.and Swanson, B.G., 2011. Antifungal effectiveness of potassium sorbate incorporated in edible coatings against spoilage molds of apples, cucumbers, and tomatoes during refrigerated storage. J. Food Sci., 76: 210-217. https://doi. org/10.1111/j.1750-3841.2011.02059.x

Miri, S., Salari, M. and Ahmadpour, A., 2018. Physicochemical Responses of 'Kinnow' Mandarins to Wax and Polyethylene Covering During Cold Storage. Open Agric., 3(1): 678683. https://doi.org/10.1515/opag-2018-0071

Montero, C.R.S., Antes, R.B., Schwarz, L.L., dos Santos, L.C., dos Santos, R.P. and Bender, R.J., 2010. Complementary physical and chemical treatments as an alternative to fungicide use to control postharvest decay incidence and fruit quality of Montenegrina tangerines. Crop Prot., 29: 1076-1083. https://doi.org/10.1016/j. cropro.2010.06.014

Nawaz, M.A., Ahmad, W., Ahmad, S. and Khan, M.M., 2008. Role of growth regulators on preharvest fruit drop, yield and quality in
Kinnow mandarin. Pak. J. Bot., 40(5): 19711981.

Nawaz, R.,Abbasi,N.A.,Khan,M.R.,Ali,I.,Hasan, S.Z.U. and Hayat, A., 2019. Color Development in 'Feutrell's Early' (Citrus Reticulata Blanco) affects peel composition and juice biochemical properties. Int. J. Fruit Sci., pp. 1-20. https:// doi.org/10.1080/15538362.2019.1699490

Neves, C.G., Do Amaral, D.O.J., de Paula, M.F.B., de Nascimento, L.S., Costantino, G., Passos, O.S. and Micheli, F., 2018. Characterization of tropical mandarin collection: Implications for breeding related to fruit quality. Sci. Hortic., 239: 289-299. https://doi.org/10.1016/j. scienta.2018.05.022

Nordby, H.E. and McDonald, R.E., 1991. Relationship of epicuticular wax composition of grapefruit to chilling injury. J. Agric. Food Chem., 39(5): 957-962. https://doi. org/10.1021/jf00005a032

Pakistan Horticultural Development and Export Board (PHDEB). 2014. Production and trade analysis, Ministry of commerce: Islamabad, Pakistan.

Palou, L., Usall, J., Munoz, J.A., Smilanick, J.L. and Vinas, I., 2002. Hot water, sodium carbonate, and sodium bicarbonate for the control of postharvest green and blue molds of Clementine mandarins. Postharvest Biol. Technol., 24: 93-96. https://doi.org/10.1016/ S0925-5214(01)00178-8

Palou, L., Smilanick, J.L. and Droby, S., 2008. Alternatives to conventional fungicides for the control of citrus postharvest green and blue moulds. Stewart Postharvest Rev. 2: 1-16. https://doi.org/10.2212/spr.2008.2.2

Rab, A., Rahman, J., Sajid, M., Ahmad, N., Ahmad, M., Nawab, K. and Ali, K., 2016. Influence of harvesting dates on fruit quality and storage performance of sweet orange (blood red) fruit. JAPS: J. Anim. Plant Sci., 26(6): 16591665.

Rajendran, P., Nandakumar, N., Rengarajan, T., Palaniswami, R., Gnanadhas, E.N., Lakshminarasaiah, U. and Nishigaki, I., 2014. Antioxidants and human diseases. Clin. Chim. Acta, 436: 332-347. https://doi.org/10.1016/j. cca.2014.06.004

Ranganna, S., 1999. Handbook of analysis and quality control for fruit and vegetable products and Ed., Tata Mc-Graw Hill publishing company Ltd, 
New Delhi

Rekha, C., Poornima, G., Manasa, M., Abhipsa, V., Devi, J.P., Kumar, H.T.V. and Kekuda, T.R.P., 2012. Ascorbic acid, total phenol content and antioxidant activity of fresh juices of four ripe and unripe citrus fruits. Chem. Sci. Trans., 1(2): 303-310. https://doi.org/10.7598/cst2012.182

Reuther, W., Batchelor, L.D. and Webber, H.J., 1967. The citrus industry. Vol. I. History, World distribution, botany and varieties.

Rokaya, P., Baral, Dilli, Gautam, D.M., Shrestha, A. and Paudyal, K., 2016. Effect of Postharvest Treatments on Quality and Shelf Life of Mandarin (Citrus reticulata Blanco). Am. J. Plant Sci., 7: 1098-1105. https://doi. org/10.4236/ajps.2016.77105

Sonkar, R.K., Sarnaik, D.A., Dikshit, S.N. and Saxena, R.R., 2009. Individual Stretch Cling Film Wrapped Kinnow Mandarin under Ambient Storage. Indian J. Hortic., 66: 22-27.

Spungen, J., 2005. Bowes and Church's food values of portions commonly used. Lippincott Williams and Wilkins.

Thaipong, K., Boonprakob, U., Crosby, K., CisnerosZevallos,L.and Byrne,D.H.,2006. Comparison of ABTS, DPPH, FRAP, and ORAC assays for estimating antioxidant activity from guava fruit extracts.J. Food Comp. Anal., 19(6-7): 669-675. https://doi.org/10.1016/j.jfca.2006.01.003

Ting, S.V., 1980. Nutrients and nutrition of citrus fruits. https://doi.org/10.1021/bk-1980-0143. ch001

Trade Development Authority of Pakistan Report, Islamabad. 2018.
United States Department of Agriculture, Agricultural Research Service. 2011. USDA National Nutrient Database for Standard Reference, Release 24. Available from: http:// www.ars.usda.gov/services/docs.htm?docid $=8964$.

Valencia-Chamorro, S.A., Pérez-Gago, M.B., del Río, M.A. and Palou, L., 2009. Curative and preventive activity of hydroxypropyl methylcellulose-lipid edible composite coatings containing antifungal food additives to control citrus postharvest green and blue molds. J. Agric. Food Chem. 57: 2770-2777. https://doi. org/10.1021/jf803534a

Venditti, T., Molinu, M.G., Dore, A., Agabbio, M. and D'hallewin, G., 2005. Sodium carbonate treatment induces scoparone accumulation, structural changes, and alkalinization in the albedo of wounded citrus fruits. J. Agric. Food Chem.53:3510-3518.https://doi.org/10.1021/ jf0482008

Wills, R., McGlasson, B., Graham, D., Joyce, D., and Rushing, J.W., 1999. Postharvest: an introduction to the physiology and handling of fruit, vegetables and ornamentals. J. Vegetable Crop Prod., 4(2): 83-84.

Youssef, K., Ligorio, A., Nigro, F. and Ippolito, A., 2012. Activity of salts incorporated in wax in controlling postharvest diseases of citrus fruit. Postharvest Biol. Technol., 65: 39-43. https:// doi.org/10.1016/j.postharvbio.2011.10.006

Zamorani, A. and Russo, C., 1974. Research on nitrogen compounds in citrus fruits. IV. Free amino acids in mandarin juice. Essenze Deriv. Agrum., 44(1): 16. 